\title{
LAND USE CHANGES OF HISTORICAL STRUCTURES IN THE AGRICULTURAL LANDSCAPE AT THE LOCAL LEVEL - HRIŇOVÁ CASE STUDY
}

\author{
MATEJ MOJSES, FRANTIŠEK PETROVIČ \\ Institute of Landscape Ecology SAS, branch Nitra, Akademická 2, P.O.Box 22, 94910 Nitra, Slovak Republic; \\ e-mail: matej.mojses@savba.sk \\ Department of Ecology and Environmental Studies, Faculty of Natural Sciences, Constantine the Philosopher \\ University, Tr. A. Hlinku 2, 94901 Nitra, Slovak Republic; e-mail: fpetrovic@ukf.sk
}

\begin{abstract}
Mojses M., Petrovič F.: Land use changes of historical structures in the agricultural landscape at the local level - Hriňová case study. Ekológia (Bratislava), Vol. 32, No. 1, p. 1-12, 2013.

The aim of this paper is to describe agricultural landscapes in the cadastral area of Hriňova and their development in the context of social and economic changes over the past 60 years. This area is characterized by the occurrence of historical structures of agricultural landscape (HSAL) which are important because they comprise various cultural, environmental and ecological aspects. The assessment of land use changes on the two scales of cadastral area and selected small localities highlights that the most important trend here is agricultural extensification. The results show that despite these changes in land use, the historical structures in the agricultural landscape represented by forms of anthropogenic relief remain a permanent part of this research area.
\end{abstract}

Key words: historical structures in the agricultural landscape, spatial pattern, landscape structure, forms of anthropogenic relief, land use.

\section{Introduction}

For the purpose of planning nature and landscape conservation, it is necessary to know the development of land use changes in order to identify the areas' conflicts with economic use. The spatial structure of the landscape, thus defining its shape and distribution, provides specific characteristics which enable characterization of any chosen part of the landscape.

Landscape is a mosaic where the mixture of local ecosystems or land uses is repeated in similar form over a kilometer-wide area (Forman, 1997), and it differs structurally in the distribution of species, energy and materials (Forman, Godron, 1986). At the same time, the land cover types on a regional scale remain close to the basic categories of the land use. Most landscapes have been influenced by anthropogenic use, and the resulting landscape mosaic is a mixture of natural and human-managed patches which vary in size, shape, arrangement, and which result from complex interactions between physical, biological and social forces (Turner, 1989). Wu and Hobbs (2002) identified land cover and land use as major research topics because these rank among the most important and challenging research areas in landscape ecology. 
Anthropogenic impacts since the early 19 th century and particularly during the 20 th century, have considerably disturbed the state of equilibrium of the landscape and have resulted in rapid landscape change, in loss of diversity and ecological capacities and also in damage to historically valuable cultural landscapes (Petit, Lambin, 2002; Van Eetvelde, Antrop, 2004; Bastian et al., 2006; Demek et al., 2008). The rapidity and magnitude of landscape changes strongly accelerated population increase and a growth in urban areas (Antrop, 2005). The changes are exacerbated by changing values, policy and economics which have adversely affected the cultural landscape (Holl, Nilsson, 1999). The intensity of these combined factors on landscape mosaics has had significant impact on landscape stability. Bastian and Bernhadt, (1993) and Miller et al., (1997) consider that biotic components are the most sensitive indicators of such landscape changes.

Agricultural land has recently begun to be perceived not only as a source of food, but also its non-productive functions have become increasingly highlighted. Environmentally friendly use of agricultural land is paramount, and its significant biotic components such as non-forest woody vegetation must be preserved to maintain its cultural, environmental and ecological aspects (Deckers et al., 2005).

As already mentioned, the landscape has changed dramatically in the last 200 years. The extent of these changes can be significantly documented when the focus is placed on linear and point features of the landscape, which play an important part in maintaining the diversity of the landscape. Linear tree structures related to production began to emerge in the 18th and 19th centuries, forming boundaries, shelter and sources of wood and other products. Western Europe is characterized by hedgerows which contribute to the visual and cultural value of the landscape and to diversity in field and typical network patterns (Burel, Baudry, 1995). In the Czech Republic, hedgerow-defined field patterns called pluzinas date back to the Late Middle Ages. This term, in medieval Czech, means "agricultural land belonging to one village", thus defining its crop fields, meadows, pastures and roads (Gojda, 2000; Sklenička et al., 2009). Similar developments in agricultural landscape structure have now been recorded in Slovakia (Hreško et al., 2010). Transformation of the cultural landscape and land use changes of the agricultural landscape in Slovakia were studied by Boltižiar, Chrastina, 2008; Blažík et al., 2011; Muchová et al., 2010.

On the whole, traditional cultural landscape represents a specific, temporally limited and spatially shrinking subtype of landscape structures. These have a fragmentary nature, as they are remnants of the former continuous landscape. Such landscape elements create a mosaic of extensively used small-scale landscape features of arable lands and permanent agricultural crops. It also comprises permanent grasslands including meadows, grasslands and abandoned orchards which are currently unused areas with a low degree of succession, and referred to as Historical Structures of the Agricultural Landscape (HSAL). The traditional cultural landscape has an impact on a wide range of landscape features which determine their sustainable use (Štefunková, Dobrovodská, 2009). A characteristic feature of HSAL is the occurrence of Forms of Anthropogenic Relief (FAR), which improve the soil-relief features. These include terraces and graded bounds which ameliorate "de-skeletonized" soils during plowing, and the accumulation of stone heaps and mounds with varying degrees of earthing (Ružičková et al., 1999). 
The studied area forms a specific type of settlement - the dispersed settlement (Petrovič, 2006), which was preserved during socialism and retains elements of the traditional cultural landscape. This area is interesting and specific in many ways, and ongoing research there is presented in several works (Oláh, 2003; Kunca et al., 2008; Oláh, Boltižiar, 2009).

The aim of this paper is to evaluate the development of land use in an area with specific HSAL on two levels. The first level determines the trends in landscape development of the entire Slovakian cadastral area of Hriňová, and the second provides detailed mapping of this area in four selected localities.

\section{Study area}

The specificity of the cadastral area of Hriňová city lies in maintaining the format of dispersed settlements with relatively original landscape structure. Maintainance of the traditional form of farming and unique landscape is due to the fact that this area was unaffected by agricultural collectivization following World War II.

The city of Hriňová lies in the northeastern part of the Zvolenská kotlina basin and is administratively part of the Banská Bystrica region and the Detva district. The model area is in the dispersed settlement situated on the deforested southern slopes of the Detvianske vrchy foothills and the western slopes of the Sihlianska planina plain in the area of Korytárky - Jasenovo. This cadastral area covers 12,643.84 hectares.

Four research areas which included all forms of anthropogenic relief were chosen for detailed mapping in the Hriňová cadastral area. In-depth research was conducted in the following research areas:

1. Hriňová-Blato (HB) - the mosaic of landscape elements here is created by arable land parcels and permanent grasslands which have varying degrees of use and several forms of anthropogenic relief,

2. Hriňová-Mesto (HM) - this locality is composed of mosaics of mostly fallow arable land modified into terraces together with permanent extensively-used sloped grasslands lacking anthropogenic relief forms,

3. Hriňová-Snohy (HS) - this area is currently dominated by extensively used permanent grasslands and small-scale landscape elements of arable land with graded bounds,

4. Hriňová-Krivec (HK) - this is an area dominated by mosaics of narrow-belt arable land and permanent grasslands with graded bounds and varying degrees of usage (Fig. 1).

\section{Methods}

Digitalization of the spatial data defining individual forms of land use was performed using the "on screen" method. It was conducted manually according to the analogue (visual) interpretation of maps and aerial orthophotos in the ArcView GIS environment.

Historical black and white (panchromatic) aerial photos from 1949 were utilized for the first period. These were provided by the Topographic Institute of the Slovak Army in Banská Bystrica. Unlike the processes used in historical maps, ortho-rectification here was performed in a digital photogrammetric system ("Orthobase" module of ERDAS IMAGINE 8.4 program) environment, using the affinity transformation method. Altitude values of a detailed digital model of terrain were acquired by digitalization of contour lines from topographic maps in the scale of 1:10 000. Orthophotos were created following triangulation of these photographs, and these were then transformed into orthophoto mosaics and interpreted by the comparison with topographic maps from 1956, in the scale of 1:25,000. Current land use in 2010 was interpreted using basic 1992-1993 maps of the Slovak Republic in the scale of 1:10,000 and from 2002/2003 orthophotos in the scale of 1:5,000 (Orthophotomaps $\odot$ Geodis Slovakia, s.r.o, 2003; Aerial photograph and digital orthophotomaps $\odot$ Eurosense s.r.o, 2003) verified by reconnaissance field survey). The secondary landscape structure of the Hriňova cadastral area was evaluated using the legend created for the Corine Land Cover project in 2000 (Feranec, Otahel', 2001). The legend for mapping localities was modified and adjusted with identifiable units at a scale of 1:2,000 (Table 1). 


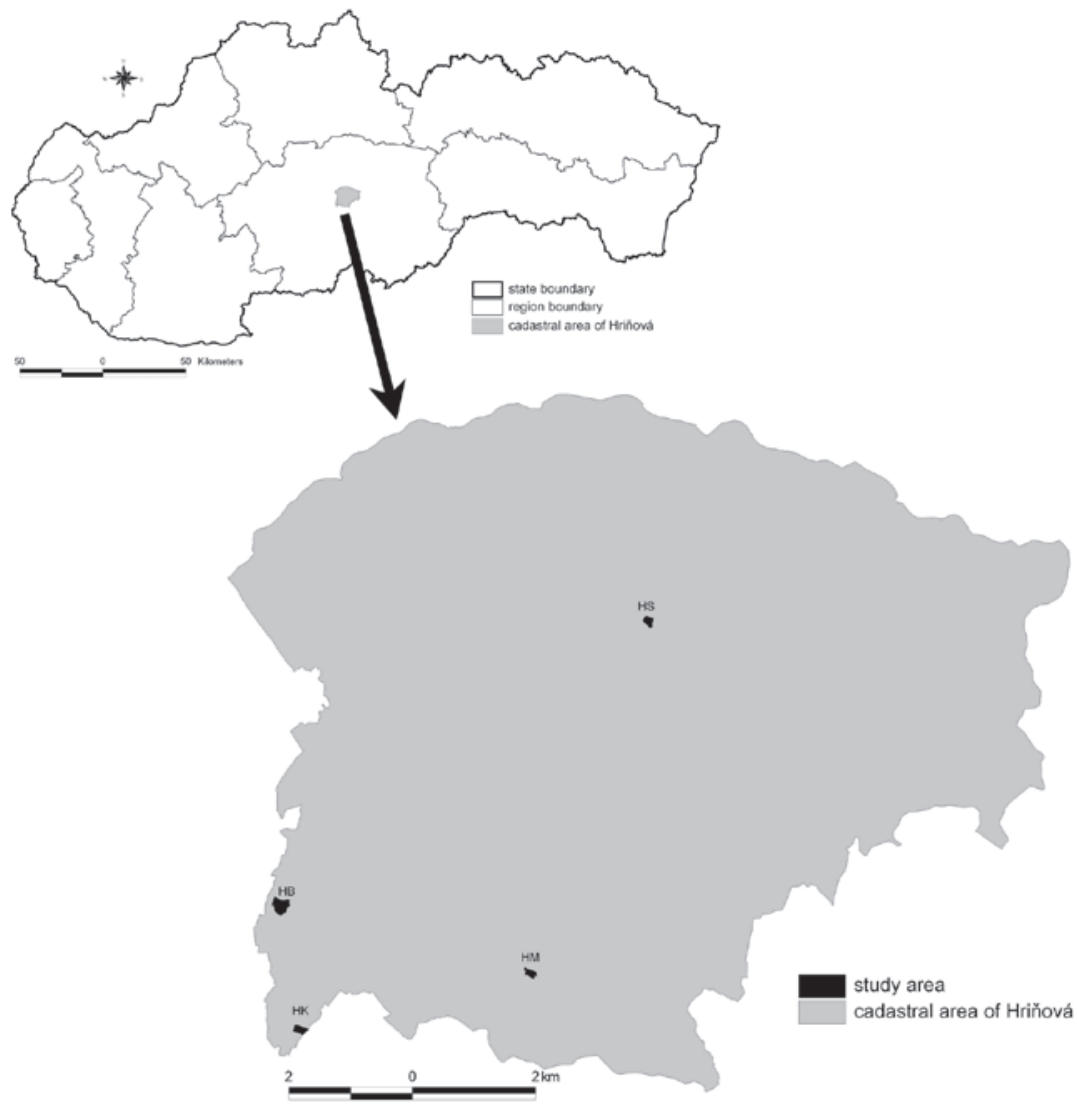

Fig. 1. Location of the research area.

Interpretation of changes in land usage was based on expert assessment of all possible combinations of land cover changes identified while comparing the map layers from two time periods (Olschofsky et al., 2006). This transformation key was then used in an algorithm, which assigned a corresponding code for the type and pressure of the given change to each record in the spatial database. This resulted in the interpretation of land changes between 1949 and 2010.

The last step comprised evaluation of configuration indicators in individual time horizons. These reflect the spatial character and physical distribution of all objects in the landscape. Spatial analyses of the landscape were conducted using the specialized Patch Analyst 2.2 (McGarigal, Marks, 1995) statistical program and they were performed using the following landscape metrics: number of patches (NP), mean patch size (MPS), total edge (TE), mean patch edge (MPE), mean shape index (MSI), Shannon's diversity index (SDI), Shannon's evenness index (SEI). 
T a b le 1. Selected land-cover categories in the four localities - on a local scale.

\begin{tabular}{|l|c|l|}
\hline Main category & Code & Sub-category \\
\hline 1 Forest and semi-natural areas & 11 & small woods \\
& 12 & solitary tree \\
& 13 & occurrence of forest trees which cover more than $50 \%$ of the surface \\
& 14 & occurrence of forest trees which cover less than $50 \%$ of the surface \\
& 15 & groups of scrub and trees \\
\hline 2 Pastures & 21 & grasslands \\
\hline 3 Agricultural areas & 31 & small-scale arable fields \\
& 32 & outfield \\
& 33 & gardens \\
\hline Transport units & 34 & orchards \\
\hline T Traditional forms of & 41 & field paths (Unpaved roads) \\
anthropogenic relief & 51 & graded bounds \\
& 52 & bounds \\
& 53 & terraces \\
\hline
\end{tabular}

\section{Results}

When evaluating types of land use changes in the cadastral area of the city of Hriňová between 1949 and2010, besides unchanged parts, 8 types of changed usage were identified - deforestation, afforestation, agricultural intensification, agricultural extensification, urbanization, de-urbanization, overgrowth and flooding. However, the studied area may still be considered stable in terms of usage, as the major part of the territory retained its mainly forest-economic use. Some areas with extensive meadow grazing and small areas of arable land have preserved their same use (Table 2).

The second most extensive type of change was agricultural extensification, which was reflected in the south-western more intensively used part of the studied area. It concerned mainly transformations of small arable lands into permanent grasslands, and overgrowth of less accessible meadows into pastures. Agricultural extensification also quite significantly influenced isolated agricutural parts of the area. Agricultural extensification was identified in 1,403 ha which is $11.1 \%$ of the total cadastral area. The opposite trend of agricultural intensification took place in a much smaller area, where it mainly involved change of pastures into meadows and the transformation of meadows near houses into arable land.

In terms of size, the next trend was the afforestation area. This covered 392 ha $(3.11 \%$ of the total area) and resulted from afforestation of marginal, less accessible and isolated pastures and meadows. Deforestation took place in only 40 ha $(0.32 \%)$. This involved forests cut down near watercourses, and its effect was most apparent in vegetation on the bank of Slatina river. 
Urbanization in this cadastral area was also a dominant trend in this landscape, especially in the central part of Velký Slanec. This occurred in 265 ha (2.1\% of the cadastral area) and the main factor here was development of industrial production in the city. To improve the accessibility of citizens to work, a lot of urban-type public housing was built in the following localities; Krivec I, Krivec II, Malý Slanec and Vel'ký Slanec. This created more dominant centres with infrastructure and services.

Although flooding was limited to a small area, its indirect impact is much more significant. The Hriňová reservoir on the Slatina river created a visually dominant element in this

T a ble 2. Areas of individual types of land use changes in the Hriňová cadastral area.

\begin{tabular}{|l|c|c|}
\hline Trends of landscape development & area (ha) & area (\%) \\
\hline Urbanization & 265.86 & 2.10 \\
\hline De-urbanization & 23.02 & 0.18 \\
\hline Agricultural intensification & 410.99 & 3.25 \\
\hline Agricultural extensification & 1403.42 & 11.10 \\
\hline Deforestation & 40.86 & 0.32 \\
\hline Afforestation & 392.99 & 3.11 \\
\hline Overgrowth & 135.73 & 1.07 \\
\hline Flooding & 52.62 & 0.42 \\
\hline No changes & 9918.35 & 78.44 \\
\hline Total & 12643.84 & 100.00 \\
\hline
\end{tabular}

landscape. Concurrently, it limited economic use of the river above it, due to implementation of water resources protection.

Similar changes in land use were recorded during evaluation of these developmental trends in the studied localities. Comparisons between 1949 and 2010 confirmed that the most significant development trend was agricultural extensification by transformation of arable land into permanent grasslands with varying intensity of use. The worst decline in agricultural usage was noted in land lying fallow without use. This was recorded in the Hriňová-Mesto locality, resulting from abandonment of traditional land use after 1989 (Table 3). This was most likely due to worsening access for agricultural machinery combined with a decrease in economic profitability. The opposite trend occurred in the Hriňová - Krivec locality where conditions for more intensive use were created following land consolidation. This created graded bounds which reduced soil erosion. HSAL gained increased percentage of the total area, most likely as a result of creation and expansion of new rock and mud-rock mounds. However, extension of line structures in the immediate vicinity of unused parcels also had some effect.

Using the chosen indicators of the spatial structure of patches, evaluation was carried out to determine how land use changes were reflected between 1949 and 2010. The main indicator of land use changes showed a decrease in allocated polygons from 182 in 1949 to the current 153. These changes were then reflected in the evaluation of our selected landscape indexes. One of these was the calculation of mean patch size. The most significant increase in mean patch size (MPS) was recorded in the Hriňová-Snohy locality. The overall size increase in 2010 caused by historical blending of parts of estates, mainly near commu- 
nications, was more than $300 \%$ compared to that in 1949. This was a change from 0.06 to 0.19 ha. An increase from 0.07 ha to 0.09 ha was also recorded in the Hriňová-Blato and Hriňová-Mesto localities, but this is partly due to the increased growth in area occurring in these localities (Table 4).

This change was also reflected in the total edge (TE) characteristic. As the number of patches diminished, their total perimeter also diminished. However, the decrease here was not as significant as in the mean patch size (MPS). We identified a $40 \%$ decrease in patch perimeter in the Hriňová-Snohy locality, a 20\% decrease in Hriňová-Krivec and 2\% decrease in Hriňová-Mesto. In contradistinction, a 7\% increase was observed in HriňováBlato due to the decrease in mean patch size.

A significant increase in the size of estates is also confirmed by mean patch edge (MPE). In Hriňová-Snohy, this indicator rose from $143 \mathrm{~m}$ to $253 \mathrm{~m}$, and this clearly identifies the agricultural intensification there. A minor increase was also recorded in Hriňová-Krivec and Hriňová-Blato. On the other hand, a decrease in mean patch edge was recorded in Hriňová-Mesto, most likely due to the increase in the number of patches in this locality.

The complexity of patch shapes was interpreted according to the mean shape index (MSI). The most regular patch shapes were recorded in Hriňová-Snohy, where their relatively oval shape became less regular between 1949 and 2010 (value of 2.20). This trend was also observed in Hriňová-Krivec and Hriňová-Blato. On the other hand, the increase in the number of patches in Hriňová-Mesto positively influenced a decrease in this value and the rounding of these parcels.

Richness, indicated by increased number of landscape elements in the studied localities, is also confirmed by Shannon's diversity index (SDI).All localities exhibited an increase, with the most significant being the 31\% increase in Hriňová-Blato. The highest increase in Shannon's evenness index (SEI) was recorded in the locality of Hriňová-Snohy (+34\%), and the greatest decrease occurred in Hriňová-Blato (-13\%).

Comparison of previous parameters in relationship to FAR enables a more detailed insight into the upkeep and current use of these HSAL. The mean value of FAR (MPS) in Hriňová-Blato and Hriňová-Krivec increased; and it is interesting that the most significant increase in the number of FAR occurred in these two exact localities. In contrast, a decrease in mean size was recorded in Hriňová-Mesto and Hriňová-Snohy. FAR attained its highest values of 0.031 ha in 1949 and 0.029 ha in 2010 in Hriňová-Snohy, This was most likely due to the small number of FAR in this locality. Although the number of FAR increased in all localities, the patch perimeters (TE) did not increase everywhere, so the maximum TE was recorded in Hriňová-Blato where 48 FAR polygons had a total perimeter of 5,821 $\mathrm{m}$ (Table 5).

The number of FAR in a locality clearly differentiates the distribution of localities according to the mean patch edge (MPE). The lowest values were recorded in Hriňová-Blato at $121 \mathrm{~m}$ compared to the highest in Hriňová-Snohy at $315 \mathrm{~m}$. With regard to the complexity of patch shapes, the mean shape index (MSI) confirmed the lowest value, and therefore the relatively most regular FAR shape, in Hriňová-Blato with the value of 2.61 in 2010. This was the result of several FAR with a regular oval perimeter. Other localities had more than twice these values. The least regular shapes were observed in the locality of HriňováKrivec, where an index value of 6.51 was recorded in 2010. 


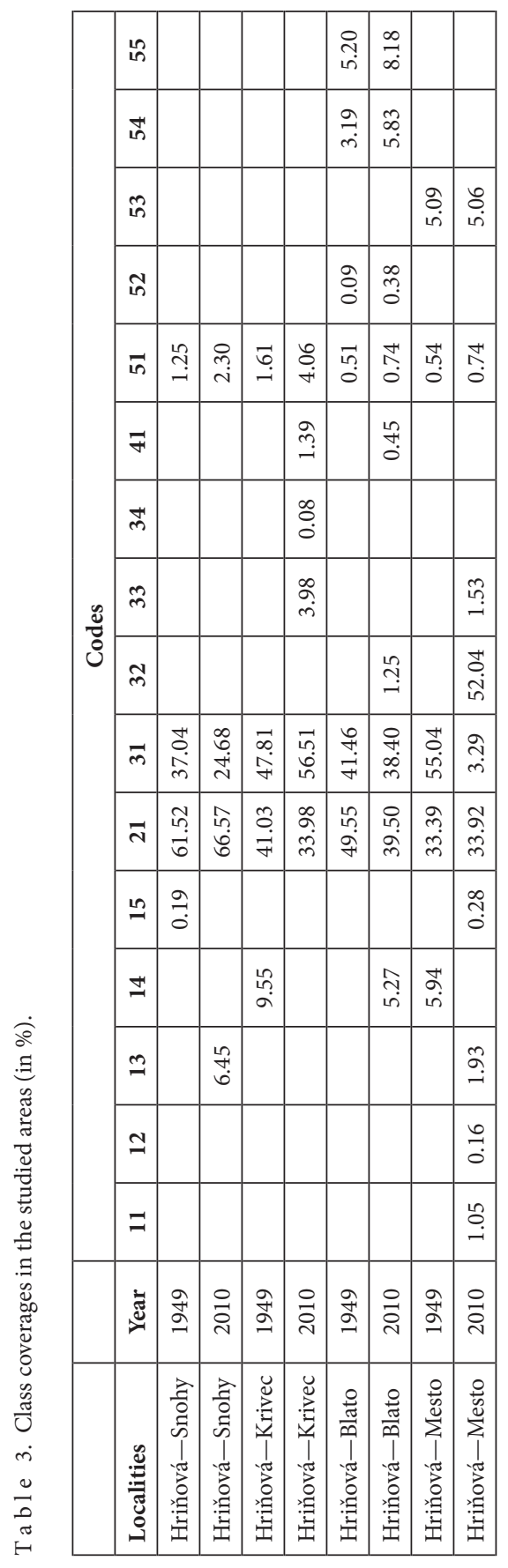

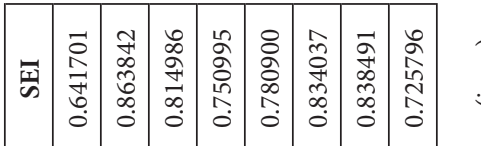

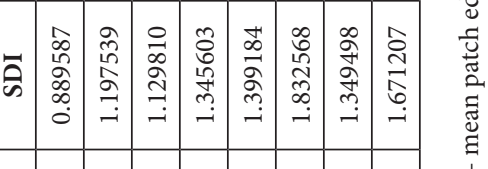

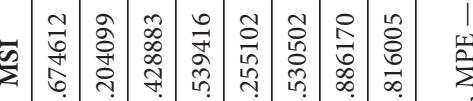

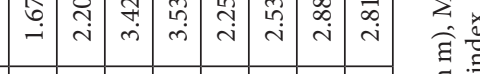

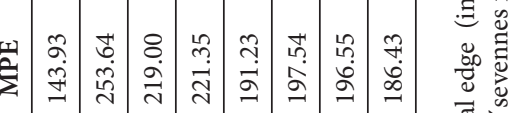

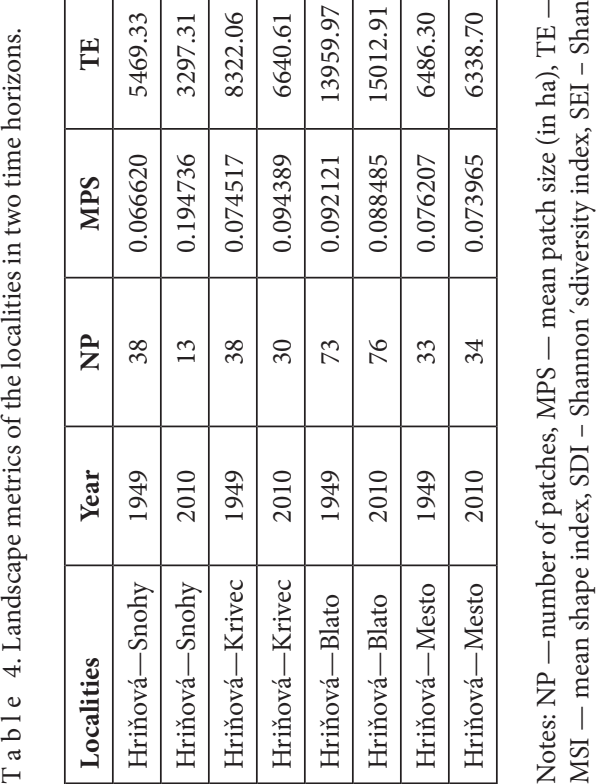
苋 : 
T a b le 5. Dynamics in the development of landscape metrics in Forms of Anthropogenic Relief (FAR) in these study areas.

\begin{tabular}{|l|c|c|c|c|c|c|}
\hline Localities & Year & NP (FAR) & MPS & TE & MPE & MSI \\
\hline Hriňová-Snohy & 1949 & 1 & 0.031667 & 334.74 & 334.74 & 5.306370 \\
\hline Hriňová-Snohy & 2010 & 2 & 0.029053 & 630.64 & 315.32 & 5.219925 \\
\hline Hriňová-Krivec & 1949 & 6 & 0.007614 & 1130.51 & 188.42 & 6.174880 \\
\hline Hriňová-Krivec & 2010 & 10 & 0.011477 & 2429.74 & 242.97 & 6.518069 \\
\hline Hriňová-Blato & 1949 & 30 & 0.020165 & 3874.46 & 129.15 & 2.584058 \\
\hline Hriňová-Blato & 2010 & 48 & 0.021192 & 5821.31 & 121.28 & 2.615854 \\
\hline Hriňová-Mesto & 1949 & 10 & 0.014179 & 2185.59 & 218.56 & 5.216937 \\
\hline Hriňová-Mesto & 2010 & 11 & 0.013264 & 2243.36 & 203.94 & 5.017807 \\
\hline
\end{tabular}

\section{Discussion}

Historical structures of agricultural landscape (HSAL) have an irreplaceable role in landscape due to their exceptional historical and aesthetical value. The aim of this study is to assess the state of these structures, and their development over time since the end of World War II in the context of social and economic change. However, it must be noted that changes in landscape are not restricted only to land use and structures (landscape elements), but they also apply to the landscape as a whole, and they influence landscape processes and functions (Palang et al., 2006). Since human economic, social and political factors have played a major role in continual development of landscape structure, understanding the development of land use changes is necessary for planning nature and landscape conservation and in identifying conflicts arising in the economic use of these elements. These have become manifested at an increased rate due to significant changes in land ownership and use in all central and eastern European countries. As a result, developmental dynamics and the actual agricultural land structure significantly changed (Lerman, 2001; Olah, Žigrai, 2004; Skokanová et al., 2012). Špulerová et al. (2011) compiled a complex inventory and classification of traditional Slovak agricultural landscape structure. One of the most well-preserved traditional cultural structures in their suggested classification is areas with scattered settlements. This is confirmed in the traditional cultural structures represented by forms of anthropogenic relief in the studied areas which remain preserved today.

Several authors reported destruction and changes in agricultural activities which could create risks to the preservation of the traditional cultural landscape (Van Eetvelde, Antrop, 2004; Agnoletti, 2007; Špulerová, 2008; Mišovičová, Pucherová, 2008; Tomčíková, 2011; Jakab, Petluš, 2012 and Šolcová, 2013). Another factor potentially endangering the continuity of such areas is depopulation (Elbakidze, Angeltram, 2007). It is of utmost importance to find solutions to these problem, because research results confirm the irreplaceable role of HSAL (Deckers et al., 2005).

Moreira et al. (2006) observed changes in landscape use in Beira Alta in north-eastern Portugal. They found a decrease in arable cultivation followed by abandonment and the development of succession with gradual afforestation. However, sustained positives include the conservation of dry stone walls and local place names associated with the landscape. Kizos 
and Koulouri (2006) reported that expansion of forest areas, urbanization, deterioration and loss of cultural features such as terraces, hedgerows, stone walls and other agriculturally-related infrastructure can lead to decreased landscape diversity.

Based on our results, it can be stated that social and economic changes, and also important changes associated with EU accession, have led to these changes, Slovakia, as a whole, is at the crossroads, and rapid decisions must be made concerning the direction our country will take. Current choices include increased abandonment and a decrease in agricultural activity, or hopefully, support of agrarian funding schemes to reverse the effects the first two choices have already inflicted on our landscape. Correct decisions will ensure, the traditional cultural landscape and the preservation of their ecological systems (Forman, Bandry, 1984; Špulerová, Petrovič, 2011).

\section{Conclusion}

Following more than 20 years of social change, our foothill grassland ecosystems still remain endangered by dilapidation processes and abandonment of more remote but less productive grasslands. This has resulted from a combination of negative factors including; inappropriate economic conditions, legislative and administrative obstacles and loss of human ties to the traditional methods of land management.

Management changes have created conditions for an increase in biotopes which previously occurred only rarely. Such biotope habitats in the study area are fallow lands, extensive and abandoned grasslands, abandoned meadows and gardens in various succession stages, and the related increase in non-forest woody vegetation. However, in terms of biodiversity, this has proven to be a positive factor, for some groups of fauna and flora.

The key future task is to preserve the traditional way of using small-scale agricultural mosaics in the landscape in combination with various forms of anthropogenic relief. This relief includes stone heaps and mounds with terraces and graded bounds which significantly contribute to current preservation, and which can promote increased biological and landscape diversity in the long-term.

Translated by the authors

English corrected by R. Marshall

\section{Acknowledgements}

The contribution was prepared within the grant project of the Ministry of Education of the Slovak Republic and the Slovak Academy of Sciences No. 2/0051/11 „Significance and ecosystem services of historical structures of agricultural landscapes" and this work was supported by the Slovak Research and Development Agency under the contract No. APVV-0669-11. 


\section{References}

Agnoletti, M. (2007). The degradation of traditional landscape in a mountain area of Tuscany during the $19^{\text {th }}$ and 20th centuries. Implications for biodiversity and sustainable management. For. Ecol. Manag., 249(1-2), 5-17. DOI:10.1016/j.foreco.2007.05.032.

Antrop, M. (2005). Why landscapes of the past are important for the future. Landsc. Urban Plann., 70(1-2), 21-34. DOI: 10.1016/j.landurbplan.2003.10.002.

Bastian, O. \& Bernhadt A. (1993). Anthropogenic landscape changes in Central Europe and the role of bioindication. Landsc. Ecol., 8 (2), 139-151. DOI: 10.1007/BF00141593.

Bastian, O., Kronert, R. \& Lipský Z. (2006). Landscape diagnosis on different space and time scales - a challenge for landscape planning. Landsc. Ecol., 21(3), 359-374. DOI: 10.1007/s10980-005-5224-1.

Blažík, T., Faltan, V., Tarasovičová, Z. \& Saksa M. (2011). Land use changes in chosen districts of various productive agricultural regions in the context of transformational processes (in Slovak). Geografický Časopis, 63(4), $301-323$.

Boltižiar, M. \& Chrastina P. (2008). Land-use changes of the lowland agricultural landscape on the example of the Nové Sady village. Geoinformation, 4, 16-35.

Burel, F. \& Baudry, J. (1995). Social, aesthetic and ecological aspects of hedgerows in rural landscapes as a framework for greenways. Landsc. Urban Plann., 33(1-3), 327-340. DOI:10.1016/0169-2046(94)02026-C.

Deckers, B., Kerselaers, E., Gulinck, H., Muys, B. \& Hermy M. (2005). Long-term spatio-temporal dynamics of a hedgerow network landscape in Flanders, Belgium. Environ. Conserv., 32(1), 20-29. DOI: 10.1017/ S0376892905001840.

Demek, J., Havlíček, M., Chrudina, Z. \& Mackovčin P. (2008). Changes in land-use and the river network of the Graben Dyjsko-Svratecký úval (Czech republic) in the last 242 years. Journal of Landscape Ecology (CZ), 1(2), $22-51$.

Elbakidze, M. \& Angeltram P. (2007). Implementing sustainable forest management in Ukraine's Carpathian Mountains: the role of traditional village systems. For. Ecol. Manag., 249(1-2), 28-38. DOI: 10.1016/j.foreco.2007.04.003.

Feranec, J. \& Otahel' J. (2001). Land cover of Slovakia. Bratislava, Slovakia: VEDA.

Forman, R.T.T. \& Bandry J. (1984). Hedgerows and hedgerow networks in landscape ecology. Environ. Manag., 8(6), 495-510. DOI: 10.1007/BF01871575.

Forman, R.T.T. \& Godron M. (1986). Landscape ecology. New York, USA: John Wiley \& Sons.

Forman, R.T.T. (1997). Some general principles of landscape and regional ecology. Landsc. Ecol., 10(3), 133 -142. DOI: $10.1007 / \mathrm{BF} 00133027$.

Gojda, M. (2000). Landscape Archaeology - development of the cultural landscape archetypes (in Czech). Praha, CZ: Academia.

Holl, A. \& Nilsson K. (1999). Cultural landscape as subject to national research programmes in Denmark. Landsc. Urban Plann., 46(1-3), 15-27. DOI:10.1016/S0169-2046(99)00035-3.

Hreško, J., Kanásová, D. \& Petrovič F. (2010). Landscape archetypes as the elements of Slovak historical landscape structure. Ekológia (Bratislava), 29(2), 158-173. DOI: 10.4149/ekol_2010_02_158.

Jakab, I. \& Petluš P. (2012). Development of a program tool for the determination of the landscape visual exposure potential. In F. Jordan \& S. E. Jorgensen (Eds.), Models of the ecological hierarchy: from molecules to the ecosphere (pp. 375-390). Amsterdam, NL: Elsevier.

Kizos, T. \& Koulouri M. (2006). Agricultural landscape dynamics in the Mediterranean: Lesvos (Greece) case study using evidence from the last three centuries. Environ. Sci. Policy, 9(4), 330-342. DOI: 10.1016/j.envsci.2006.02.002.

Kunca, V., Gallay, I., Gallayová, Z., Olah, B., Škvareninová, J., Šteffek, J. \& Wiezik M. (2008). Anthropogenic loads and biodiversity in the selected neovulcanites in the Middle Slovakia (in Slovak). Zvolen, SK: TU Zvolen.

Lerman, Z. (2001). Agriculture in transition economies: from common heritage to divergence. Agricultural Econonics, 26(2): 95-114. DOI:10.1111/j.1574-0862.2001.tb00057.x.

McGarigal, K. \& Marks B.J. (1995). FRAGSTATS: spatial pattern analysis program for quantifying landscape structure [computer software]. Portland, USA: Department of Agriculture, Forest Service, Pacific Northwest Research Station.

Miller, J.N., Brooks, R.P. \& Croonquist M.J. (1997). Effects of landscape pattern on biotic communities. Landsc. Ecol., 12(3), 137-153. DOI: 10.1023/A:1007970716227. 
Mišovičová, R. \& Pucherová Z. (2008). The classification of Nitra's town contact area and selected villages in its hinterland. Problemy Ekologii Krajobrazu, 20, 299-305.

Moreira, F., Queiroz, I. \& Aronson J. (2006). Restorian principles applied to cultural landscapes. J. Nat. Conserv., 14(3-4), 217-224. DOI:10.1016/j.jnc.2006.05.007.

Muchová, Z., Dumbrovský, M., Váchal, J., Ručková, A. \& Váchalová R (2010). Long-Term Evolution of the Landscape Highlighted by Descriptive Statistics (in Slovak). Littera Scripta, 3(1-2), 190-203.

Oláh, B. (2003). Land use development of Podpolanie - management of the Polana Biosphere Reserve transition zone (in Slovak). Zvolen, SK: TU Zvolen.

Oláh, B. \& Žigrai F. (2004). The meaning of the time-spatial transformation of the landscape for its sustainable use (a case study of the transition zone of the Polana Biosphere Reserve). Ekológia (Bratislava), 23(Suppl. 1), 231-243.

Oláh, B. \& Boltižiar M. (2009). Land use changes within the Slovak biosphere reserves' zones. Ekológia (Bratislava), 28(2), 127-142. DOI:10.4149/ekol_2009_02_127.

Olschofsky, K., Köhler, R., Gerard, F., Thomson, A., Manchester, S., Smith, G., Wadsworth, R., Swetnam, R., Petit, S., Gregor, M., Luque, S., Huitu, H., Hazeu, G., Mucher, S., Halada, L., Bugár, G. \& Pino J. (2006). Land cover change in Europe from the 1950'ies to 2000. Hamburg, GER: Institute for Worldforestry, University of Hamburg.

Palang, H., Printsmann, A., Konkoly Gyuró, E., Urbanc, M., Skowronek, E. \& Woloszyn, W. (2006). The forgotten rural landscapes of Central and Eastern Europe. Landsc. Ecol., 21(3), 347-357. DOI: 10.1007/s10980-0044313-x.

Petit, C.C. \& Lambin E.F. (2002). Impact of data integration technique on historical land-use/land-cover change: Comparing historical maps with remote sensing data in the Belgian Ardennes. Landsc. Ecol., 17(2), 117-132. DOI:10.1023/A:1016599627798.

Petrovič, F. (2006). The changes of the landscape with dispersed settlement. Ekológia (Bratislava), 25(1), 65-89.

Ružičková, H., Dobrovodská, M. \& Valachovič M. (1999). Landscape-ecological evaluation of vegetation in relation to the forms of anthropogenic relief in the cadastre of the Liptovská Teplička village, the Nízke Tatry Mts. Ekológia (Bratislava), 18(4), 381-400.

Sklenička, P., Molnarova, K., Brabec, E., Kumble, P., Pittnerova, B., Pixova, K. \& Salek M. (2009). Remnants of medieval field patterns in the Czech Republic: analysis of driving forces behind their disappearance with special attention to the role of hedgerows. Agric. Ecosyst. Environ., 129(4), 465-473. DOI:10.1016/j.agee.2008.10.026.

Skokanová, H., Havlíček, M., Borovec, R., Demek, J., Eremiášová, R., Chrudina, Z., Mackovčin, P., Rysková, R., Slavík, P., Stránská, T. \& Svoboda J. (2012): Development of land use and main land use change processes in the period 1836-2006: case study in the Czech Republic. Journal of Maps, 8(1), 88-96. DOI:10.1080/174456 47.2012.668768.

Šolcová, L. (2013): Landscape development of dispersed settlement in the Novobanská štálová area (in Slovak). Nitra, SK: UKF Nitra.

Špulerová, J. (2008): Land use changes in the Veselovianka river catchment in the Horná Orava region. Ekológia (Bratislava), 27(3), 326-337.

Špulerová, J. \& Petrovič F. (2011). Historical agricultural landscape as a subject of landscape ecological research. Hrvatski Geografski Glasnik, 73(2), 155-163.

Špulerová J., Dobrovodská M., Lieskovský J., Bača A., Halabuk A., Kohút F., Mojses M., Kenderessy P., Piscová V., Barančok P., Gerhátová K., Krajčí J. \& Boltižiar M. (2011): Inventory and classification of historical structures of the agricultural landscape in Slovakia. Ekológia (Bratislava), 30(2),157-170. DOI:10.4149/ekol_2011_02_157.

Štefunková, D. \& Dobrovodská M. (2009). Preserved European cultural heritage in agrarian landscape of Slovakia. Tájökológiai Lapok, 7(2), 283-290.

Tomčíková, I. (2011). The river landscape structure of Smrečianka river (in Slovak). Ružomberok, SK: VERBUM.

Turner, M.G. (1989). Landscape ecology: the effect of pattern on process. Annu. Rev. Ecol. Syst., 20, 171-197. DOI: 10.1146/annurev.es.20.110189.001131.

Van Eetvelde, V. \& Antrop M. (2004). Analyzing structural and functional changes of traditional landscapes - two examples from Southern France. Landsc. Urban Plann., 67(1-4), 79-95. DOI:10.1016/S0169-2046(03)000306.

Wu, J. \& Hobbs R. (2002). Key issues and research priorities in landscape ecology: an idiosyncratic synthesis. Landsc. Ecol., 17(4), 355-365. DOI:10.1023/A:1020561630963. 